\title{
POSSIBILITIES FOR INTRODUCING A NEW NIGHT TRAIN CONNECTION IN MIDDLE EUROPE
}

\begin{abstract}
Liberalisation of the rail transport market is the main aim of the European Union in the field of transport policy. Open access on the market allows railway undertakings to provide their services, but it also requires to compete with each other. In recent years, night train services have experienced a renaissance, especially in west-Europe countries. A development of this type of services is important to achieve the goal of carbon neutrality in EU, especially in context of affordable air transport. The aim of this study is to analyse current night train services in middle Europe and find opportunities for their further development. In this article we have proposed new night train connections between Hungary, Slovakia, Czech Republic, and Germany, provided by railway undertaking in open access mode, with a detailed cost calculation. This is necessary to assess the economic efficiency of introducing new connections. Results of the cost calculations form the basis of the price for transport on newly introduced routes.

Keywords: Open Access; Railway transport market; Night train services; Middle Europe; Cost calculation; Economic efficiency
\end{abstract}

\author{
Igor Dömény ${ }^{1}$ \\ ${ }^{1}$ Faculty of Operation and Economics of Transport and Communications; University of Žilina, \\ Univerzitná 8215/1,01026 Žilina; +421/41513 3434; igor.domeny@stud.uniza.sk \\ Anna Dolinayová ${ }^{2}$ \\ ${ }^{2}$ Faculty of Operation and Economics of Transport and Communications; University of Žilina, \\ Univerzitná 8215/1, 01026 Žilina; +421/41 513 3424; anna.dolinayova@fpedas.uniza.sk
}

\section{Introduction}

The share of international long-distance passenger rail transport has been constantly declining compared to the air transport in recent years. The development of lowcost companies had a significant impact to make air transport available for general public. Railway transport on conventional routes with a length more than $1000 \mathrm{~km}$ has become less flexible, and the travel time and fares have become uncompetitive. This situation led railway undertakings in Europe to reduce international longdistance connections, especially night connections, due to their low profitability.

Despite these facts, in las few years several night train connections have been re-estabilished, especially in Austria, Germany, Switzerland and Sweden. There are several reasons for gradual increase in this segment. Liberalisation of rail transport market has introduced open competition and allowed market access for all undertakings. Also, efforts to protect the environment and to reduce the negative effects of the climate crisis affects the behaviour of society. Railway transport as the most ecological-friendly mode of public transport can play an important role in achieving the carbon neutrality of the EU. However, to achieve this aim, it is necessary to increase competitiveness of long-distance rail transport for example through efficient pricing and providing added value for the passenger.

In literature we can find several studies dealing of the issue of night train connections. Manthei (2005) presents an up-to-date overview of the European night train services comprising of 180 scheduled train services in 15 countries. Author also presents a concept for a combined passenger train car that could be used for day as well as night train services. Gunkel et al. (2007) proposed and compared in their research two new approaches to support queries for night train connections. Its purpose is to find all train connections which are attractive from a costumer point of view. Li et al. (2019) dealt with analysis and prediction of passenger flow of high-speed night train in China. Their study result can provide certain data support to the reasonable operation of high-speed night train under network condition.

\section{Analysis of current night train connections in Europe}

Night trains in Europe are provided mostly by domestic railway undertakings or undertakings consisting of two or more incumbents. Predominance of incumbents in this sector can be seen especially in East and South part of Europe. There are also several private railway undertakings providing mostly seasonal night connections, like Swedish company Snalltaget on the route Berlin Malmö operated during the summer months. The largest reduction of the night trains took place in the west part of Europe (France, Germany). After the termination of night connections operated by German incumbent Deutsche Bahn under the brand City Night Line (CNL), the service on some CNL routes was replaced by ÖBB Nightjet services. ÖBB Nightjet as a subsidiary of Austrian state incumbent $\mathrm{OBB}$ is currently the biggest railway undertaking providing night trains services in Europe. Its trains are operated in Austria, Germany, Switzerland, Italy, Belgium and in partnership with other domestic incumbents also in Slovakia, Czech Republic, Poland, Hungary, Slovenia and Croatia. Network of ÖBB Nightjet 
night connections operated in year 2020 can be seen at figure 1 (nightjet.com, 2021).

The development of night connections is also visible as well in Sweden. Domestic incumbent SJ provides inland trains from south of the country to nord, and one pair of international connection from Stockholm to Narvik in Norway (named as Arctic Circle Train). Other companies operating night trains across Europe are Thello (consisted of Italian and France incumbents) on the route from Milan to Paris, Snalltaget and domestic incumbents in another European countries. Most of them provides also inland night connections or trains to neighboring countries (railguideeurope.com, 2021).

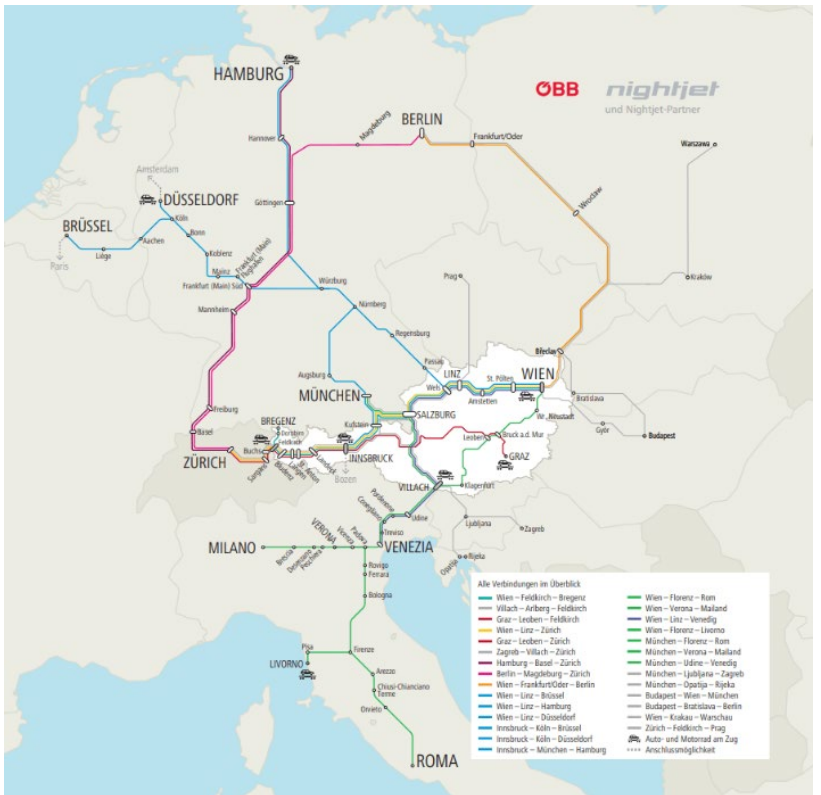

Fig. 1. Network of ÖBB Nightjet night train connections in year 2020 (Source: www.railguideeurope.com)

Situation in the middle Europe countries has been in recent years similar to the global scale. Most countries excluded night trains from PSO contracts, which resulted in a reduction of these connections that were economically unprofitable. Fast development of low-cost air transport undertakings has made these trains less flexible and more expensive for passengers. One of the biggest disadvantages of long-distance international trains in middle Europe is long travel time due to outdated infrastructure. This can be in the segment of night transport compensated by value added services and developing passengers' environmental awareness.

For the purposes of this study, we have analysed night connections between V4 countries - Slovakia, Czech Republic, Poland, Hungary and also from these countries to the west part of Europe. From Slovakia to Czech Republic are night trains services provided by incumbent České Dráhy (ČD) and Železničná spoločnost' Slovensko (ZSSK) and also by private Czech railway undertakings Regio Jet and Leo Express. The most frequented route is between Prague and Košice, the second biggest city in Slovakia situated in east part of the country. The average travel time between these two cities is 9 hours and 13 minutes. ČD and ZSSK nowadays operate one pair of night trains on route Prague - Košice - Humenné, Regio Jet one pair of trains on route Prague - Košice and Leo Express also one pair of night trains between Prague and Prešov. There was gradual reduction of night trains provided by incumbents, from three to one pair per day, but at the same time development of connections operated by private railway undertakings. This means, that the demand of passengers on this route is high, however services provided by incumbents are not attractive for them. Compared to private undertakings, there is an absence of effective pricing and the amount of operating costs is higher.

ÖBB Nightjet in cooperation with domestic incumbents operate one pair of night train on the route Wien - Břeclav - Bohumín - Wroclav - Berlin, with direct wagons from Budapest and Bratislava. In the direction from Slovakia and Czech repubic to Poland, domestic incumbents provide their services on several routes, for example Prague - Warsaw, Žilina - Gdynia and seasonal connections from Bohumín to Baltic destinations Hel, Świnoujście and Kołobrzeg (nightjet.com, 2021).

In table 1 we can see current night train connections from Middle Europe (Slovakia, Czech Republic, Poland, Hungary) with their frequency during the week and total travel time from the station of departure to the arrival station.

Table 1. Current night train connections in Middle Europe

\begin{tabular}{lccc} 
Route & $\begin{array}{c}\text { Number of } \\
\text { night trains }\end{array}$ & Operator & Travel time \\
\hline Košice - Praha & 1 pair & incumbents & 10 hod \\
& 1 pair & Regio Jet & 8 hod $41 \mathrm{~min}$ \\
Prešov - Praha & 1 pair & Leo Express & 9 hod $19 \mathrm{~min}$ \\
Budapest - Berlin & 1 pair* & incumbents & 11 hod $2 \mathrm{~min}$ \\
Budapest - Warszawa & 1 pair* & incumbents & 14 hod $2 \mathrm{~min}$ \\
\hline * Direct wagons in cooperation with OBB Nightjet & \\
(Source: authors by zssk.sk, cd.cz, regiojet.cz, leoexpress.com)
\end{tabular}

Most of this trains are operated by incumbents (ZSSK, ČD, MÁV and PKP IC). Private railway undertakings provide their night services on the route from Košice / Prešov (the second and third largest cities in Slovakia) to capital of Czech Republic Praha. Travel time of Regio Jet night trains on this route is an hour and 19 minutes shorter than in the case of incumbents. If we compare the services provided in these trains, Leo express offers only seat wagons, Regio Jet seat and sleeping wagons and incumbents offer all types of night services (seat, couchette and sleeping).

\section{Theoretical background and methods}

In case of proposing a new rail connection, it is necessary to evaluate their economic efficiency. The methodology for determining the price for transport when introducing a new connection consists of these main steps:

- demand analysis,

- market analysis,

- analysis of customers,

- transport characteristics,

- set of wagons, 
- set of locomotives,

- determination of the required number of locomotives and wagons,

- deciding on the lease or purchase of rolling stock,

- preparation of rolling stock circulations and determining the number of required vehicles,

- preparation of staff shifts and determining the number of locomotive and train crew members,

- formation of technology of transport,

- costs calculation,

- setting the price for transport (Dolinayova et al., 2018).

The most important step for our study and evaluating the economic efficiency of proposed trains is the cost calculation. This process also forms the basis for determining the price for transport. The first step is to quantify total costs for each route and for the different expected train occupancy. Then we can quantify the unit costs per unit volume (usually per passenger, train kilometre or passenger kilometre).

Total costs consist of direct and indirect costs. Direct costs can be calculated per specific unit of volume (operational performance, transport performance) and are related to the operation of the train connection. In general, direct or operational cost can be divided into:

- locomotive costs $\mathrm{C}_{\mathrm{L}}-$ calculated as a product of the average kilometre run of locomotives $(1 \mathrm{~km})$ and the avarege cost rate per locomotive kilometre $\left(\mathrm{C}_{\mathrm{RL}}\right)$. The cost rate includes depreciation, maintenance and repairs costs and costs spent on certification of the locomotive and annual insurance.

$$
C_{L}=C_{R L} * l k m
$$

- wagon costs $\mathrm{C}_{\mathrm{W}}$ - calculated as a product of the average kilometre run of wagons (wkm) and the avarege cost rate per wagon kilometre $\left(\mathrm{C}_{\mathrm{RW}}\right)$. The cost rate includes depreciation, maintenance and repairs costs and costs spent on certification of the wagon and annual insurance.

$$
C_{W}=C_{R W} * w k m
$$

- personal costs $C_{P}$ - calculated as a product of the average employee hours (eph) and the avarege cost rate per employee $\left(\mathrm{C}_{\mathrm{RP}}\right)$. The cost rate includes the wage, social and health insurance costs, diet, accommodation, education costs and other costs as ensuring the work clothes and protective equipment. we can distinguish two basic groups of this cost item - costs of locomotive crew and train crew.

$$
C_{P}=C_{R P} * e p h
$$

- infrastructure costs - represent price for the use of railway infrastructure, which is usually regulated. This cost item must be calculated separately for individual parts of route in different countries. Methodology for the determination of price for the use of railway infrastructure is set by the infrastructure manager in each country. The amount of the charge is dependent on various factors, mostly on train-kilometres, train weight, route allocation method, category of the railway route or parameters of vehicles.
- energy costs $C_{E}$ - calculated as a product of the operating performance in gross tonne kilometres $(\mathrm{gtkm})$ and the average cost rate per energy unit $\left(\mathrm{C}_{\mathrm{RE}}\right)$. This cost rate depends on unit price of the traction energy ( $\mathrm{kWh}$ in case of electric trains, litres of fuel in case of diesel trains) and energy consumption of the locomotive/multiple units.

$$
C_{E}=C_{R E} * g t k m
$$

(Dolinayova, Nedeliakova, 2015)

Indirect costs or overhead costs form a cost item, that cannot be directly attribute to a unit of volume. This includes operational, administrative and sales overheads. Their amount can be determined based on different methods of calculating indirect costs, as division calculation, by mark-up or using activity-based costing $(\mathrm{ABC})$. In this study, we will calculate indirect costs as a percentage of the total costs of the railway undertaking for operation of specific service (Dolinayova, Nedeliakova, 2015).

Unit costs represent the amount of total costs expressed per unit of performance, most common operating performance (train $\mathrm{km}$ ) or transport performance (passenger km). The amount of unit costs depends also on the expected train occupancy.

\section{Proposal of new night train connections in middle Europe}

Based on current night train connection offer and demand between European capitals and major cities, we have proposed new trains in central Europe countries, including a detailed cost calculation, which forms the basis for determining the possible amount of fares. The proposed trains would run on these lines:

- Budapest - Hamburg - one pair of night trains,

- Košice - Budapest - one pair of day trains (which need arose in order to maintain the effectivity of trainset circulation),

- Košice - Pardubice - one pair of night trains with direct wagons to Hamburg.

Table 2 represents approximated timetables of all trains. Departure and arrival times were estimated considering the infrastructure parameters in each country and sufficient length of sleep for passengers from all metropoles, like Budapest, Bratislava, Košice, Brno, Berlin and Hamburg. Trains are also usable for passengers from Praha in direction to Germany as day connection. 
Table 2. Timetables of proposed trains (Source: authors)

\begin{tabular}{|c|c|c|c|c|c|}
\hline \multirow{2}{*}{ Station } & \multicolumn{2}{|c|}{ IC 190} & & \multicolumn{2}{|c|}{ IC 191} \\
\hline & arr. & dep. & & arr. & dep. \\
\hline Košice & & $12: 00$ & Budapest Keleti & & $12: 00$ \\
\hline Miskolc & $13: 20$ & $13: 23$ & Hatvan & 13:05 & 13:07 \\
\hline Fuzesabony & $13: 58$ & 14:00 & Fuzesabony & $13: 40$ & $13: 42$ \\
\hline Hatvan & $14: 33$ & $14: 35$ & Miskolc & $14: 17$ & $14: 20$ \\
\hline Budapest Keleti & $15: 40$ & & Košice & $15: 40$ & \\
\hline \multirow{2}{*}{ Station } & \multicolumn{2}{|c|}{ EN 482} & \multirow{2}{*}{ Station } & \multicolumn{2}{|c|}{ EN 483} \\
\hline & arr. & dep. & & arr. & dep. \\
\hline Košice & & $20: 29$ & Pardubice hl. n. & & $2: 10$ \\
\hline Kysak & $20: 41$ & $20: 48$ & Olomouc hl. n. & $3: 35$ & $3: 45$ \\
\hline Poprad-Tatry & $21: 39$ & $21: 49$ & Ostrava hl. $\mathrm{n}$. & $3: 51$ & 4:00 \\
\hline Štrba & $22: 09$ & $22: 15$ & Bohumín & 4:06 & $4: 36$ \\
\hline Liptovský Mikulás & $22: 41$ & $22: 50$ & Čadca & $5: 26$ & $5: 33$ \\
\hline Ružomberok & 23:07 & $23: 13$ & Žilina & $5: 55$ & 6:05 \\
\hline Žilina & 23:56 & $0: 06$ & Ružomberok & $6: 49$ & $6: 54$ \\
\hline Čadca & $0: 28$ & $0: 38$ & Liptovský Mikulás & $7: 11$ & $7: 16$ \\
\hline Bohumín & $1: 28$ & $1: 40$ & Štrba & 7:42 & $7: 47$ \\
\hline Ostrava hl. $\mathrm{n}$. & 1:46 & $1: 55$ & Poprad-Tatry & 8:07 & $8: 17$ \\
\hline Olomouc hl. n. & 3:01 & $3: 10$ & Kysak & 9:09 & $9: 14$ \\
\hline Pardubice hl. $\mathrm{n}$. & 4:35 & & Košice & $9: 26$ & \\
\hline \multirow{2}{*}{ Station } & \multicolumn{2}{|c|}{ EN 474} & \multirow{2}{*}{ Station } & \multicolumn{2}{|c|}{ EN 475} \\
\hline & arr. & dep. & & arr. & dep. \\
\hline Budapest Keleti & & 18:50 & Hamburg Altona & & $17: 30$ \\
\hline Gyor & $20: 10$ & $20: 15$ & Hamburg Hbf & $17: 40$ & $17: 50$ \\
\hline Rajka & 20:50 & 20:55 & Berlin $\mathrm{Hbf}$ & 19:50 & $20: 10$ \\
\hline Bratislava Petržall & $21: 12$ & $21: 20$ & Dresden $\mathrm{Hbf}$ & $21: 55$ & $22: 02$ \\
\hline Bratislava N.M. & $21: 35$ & $21: 43$ & Děčín & $22: 52$ & $22: 57$ \\
\hline Bratislava hl. st. & $21: 50$ & $22: 00$ & Ústí nad Labem & $23: 12$ & $23: 20$ \\
\hline Břeclav & $22: 50$ & $23: 10$ & Praha - Holešovic & $0: 20$ & $0: 30$ \\
\hline Brno hl. n. & $23: 40$ & 23:50 & Pardubice hl. n. & $1: 30$ & $2: 40$ \\
\hline Pardubice hl. $\mathrm{n}$. & $1: 20$ & $5: 13$ & Brno hl. n. & 4:10 & $4: 20$ \\
\hline Praha - Holešovic & 6:13 & $6: 20$ & Břeclav & $4: 50$ & $5: 25$ \\
\hline Ústí nad Labem & $7: 20$ & $7: 25$ & Bratislava hl. st. & $6: 15$ & $6: 25$ \\
\hline Děčín & 7:40 & 7:45 & Bratislava N.M. & $6: 32$ & $6: 42$ \\
\hline Dresden $\mathrm{Hbf}$ & $8: 35$ & $8: 40$ & Bratislava Petržal & $6: 55$ & 7:02 \\
\hline Berlin $\mathrm{Hbf}$ & $10: 25$ & $10: 35$ & Rajka & 7:19 & 7:22 \\
\hline Hamburg Hbf & $12: 35$ & $12: 45$ & Gyor & $7: 57$ & $8: 02$ \\
\hline Hamburg Altona & 12:55 & & Budapest Keleti & $9: 22$ & \\
\hline
\end{tabular}

Decision on rolling stock set for suggested performances was made taking into account the need for an interoperable locomotive eligible for operation in all countries, sufficient capacity of wagons and differentiation of standard services for night trains (especially sleeping and couchette cars). For every trainset we have chosen a uniform form, in order to ensure efficient rolling stock circulation. The final form of the trainset consists of:

- 3 modernized open-space seat wagons with AC (Bmpz);

- 1 modernized couchette wagon with $\mathrm{AC}$ and section for immobile passengers (Bcmz);

- 2 modernized sleeping wagons with AC (WLABmee).

The total capacity of each trainset is 252 seats in the seat section, 52 in couchette section and 52 in sleeping section. Night train on the route Budapest - Hamburg in the section from Pardubice to Hamburg and back will consist of two connected trainsets with a given capacity. Figure 2 presents the trainset circulation, divided into 4 days cycles. The total need is 4 trainsets with average daily run of each $1095 \mathrm{~km}$. The total need of locomotive park is $3+1$ backup multisystem locomotives Traxx MS3, with average daily run of each $1460 \mathrm{~km}$.

The first step of the cost calculation is to quantify the performance indicators for the period of one year and then to calculate the average cost rate related to a specific indicator. For locomotive cost we select train kilometres, for wagon costs wagon kilometres, for personal costs train kilometres and for energy costs gross-ton kilometres. Calculation of the infrastructure charges depends on the currently valid national methodology, but as a general the individual parts of the fee are charged in relation to train and gross-tone kilometres. Cost rates have been calculated according to the methodology in theoretical part of this article. Resulting rates are summarized in the Table 3 . The wagon cost rate we calculated separately for seat wagons in the personal ownership of the railway undertaking, and for couchette and sleeping wagons which the RU leases from the leasing company. A higher amount of these rates is caused mainly by the special equipment and configuration of wagons, as well as the increased maintenance requirements of this equipment. Locomotive and train crew cost rates were calculated separately for middle Europe countries (Slovakia, Czech Republic, Hungary) and Germany, due to the different standard of living and labour costs in these two parts of Europe.

Table 3. Calculated cost rates (Source: authors)

\begin{tabular}{lll}
\hline locomotive cost rate & & $0,93 \mathrm{EUR} /$ lockm \\
wagon cost rate & seat & $0,52 \mathrm{EUR} /$ wagkm \\
& couchette & $0,75 \mathrm{EUR} /$ wagkm \\
& sleeping & $0,73 \mathrm{EUR} /$ wagkm \\
locomotive crew cost rate & $\mathrm{SK}+\mathrm{CZ}+\mathrm{HU}$ & $0,48 \mathrm{EUR} /$ trainkm \\
& $\mathrm{DE}$ & $0,55 \mathrm{EUR} /$ trainkm \\
train crew cost rate & $\mathrm{SK}+\mathrm{CZ}+\mathrm{HU}$ & $0,33 \mathrm{EUR} /$ trainkm \\
& $\mathrm{DE}$ & $0,40 \mathrm{EUR} /$ trainkm \\
traction energy cost rate & & $0,005 \mathrm{EUR} /$ grosstkm \\
\hline
\end{tabular}

The amount of total costs we quantified for each route at different expected train occupancy (from $30 \%$ as a lower limit to full occupancy). Results are summarized in Table 4, for the most important routes between major cities on the train path. Unit costs are calculated for one passenger on the specific route, depending on the total amount of passengers in the train at different train occupancy. The amount of unit costs is presented in Table 5. It also forms the lower limit of the price for transport.

By setting the price for transport, the railway undertaking must take into account the risk of nonutilization of the train, or different utilization due to uneven passenger flows during the week or day (peak and off-peak days/time). 
Table 4. Total costs in EUR (Source: authors)

\begin{tabular}{|c|c|c|c|c|c|c|c|c|}
\hline & $0 \%$ & $40 \%$ & $\%$ & $0 \%$ & $70 \%$ & $0 \%$ & $90 \%$ & $100 \%$ \\
\hline ice & 525 & 95,66 & 66 & 38 & 06,75 & 11 & 47 & 3117,84 \\
\hline & & & & & & & & \\
\hline & 48 & 95,41 & 34 & 27 & 19 & & 05 & 0,98 \\
\hline in & 2,14 & 4704,68 & 327,22 & 76 & 30 & & ,37 & 39,91 \\
\hline & & 0,80 & & & & & & 3,22 \\
\hline b & 46 & 2,34 & 23 & 12 & 1,01 & & & 5019,67 \\
\hline & & 5721,19 & & 3,40 & 01 & & & 6312,83 \\
\hline & & & & & & & & \\
\hline & &, 50 & 44 & 37 & 31 & & & 4,13 \\
\hline & ,20 & 5,15 & 10 & 18 & 3,99 & & & 22,83 \\
\hline Bra & & & & & & & & 99 \\
\hline & & 114 & & & & & & 8,32 \\
\hline & 61 & 152 & 72 & 160 &, 84 & 90 & 96 & 7,02 \\
\hline & & 78 & & &, 73 & & & 1,69 \\
\hline & 13201,42 & 13328,40 & 13455,39 & 13582,37 & 13709,36 & 13836,34 & 13963,33 & 14090,31 \\
\hline & 7772,18 & & & & & & & \\
\hline Praha Holešovice - Hamburg Hbf & 11512,82 & 11786,12 & 12059,41 & 12332,71 & 12606,00 & 12879,29 & 13152,59 & 13425,88 \\
\hline
\end{tabular}

Table 5. Unit costs in EUR (Source: authors)

\begin{tabular}{|c|c|c|c|c|c|c|c|c|}
\hline occupancy & $30 \%$ & $40 \%$ & $50 \%$ & $60 \%$ & $70 \%$ & $80 \%$ & $90 \%$ & $100 \%$ \\
\hline Budapest - Košice & 34,54 & 26,69 & 21,95 & 18,66 & 16,42 & 14,74 & 13,42 & 12,37 \\
\hline Miskolc - Košice & 15,54 & 11,92 & 9,75 & 8,24 & 7,21 & 6,43 & 5,83 & 5,34 \\
\hline Košice - Pardubice hl.n. & 49,95 & 38,43 & 31,72 & 27,09 & 23,79 & 21,40 & 19,47 & 17,98 \\
\hline Poprad-Tatry - Pardubice hl.n. & 42,82 & 32,90 & 27,12 & 23,13 & 20,29 & 18,23 & 16,57 & 15,28 \\
\hline Žilina - Pardubice hl.n. & 32,88 & 25,18 & 20,69 & 17,60 & 15,40 & 13,80 & 12,51 & 11,51 \\
\hline Budapest - Bratislava hl. st. & 42,80 & 32,46 & 26,43 & 22,28 & 19,32 & 17,17 & 15,44 & 14,10 \\
\hline Budapest - Brno hl. n. & 52,55 & 40,01 & 32,70 & 27,66 & 24,07 & 21,46 & 19,36 & 17,73 \\
\hline Budapest - Praha Holešovice & 49,71 & 38,10 & 31,19 & 26,49 & 23,17 & 20,71 & 18,77 & 17,23 \\
\hline Budapest - Berlin Hbf & 81,29 & 62,53 & 51,36 & 43,76 & 38,40 & 34,42 & 31,29 & 28,81 \\
\hline Budapest - Hamburg Hbf & 104,59 & 80,54 & 66,23 & 56,48 & 49,61 & 44,51 & 40,49 & 37,31 \\
\hline Bratislava hl. st. - Praha Holešovice & 38,02 & 29,04 & 23,69 & 20,06 & 17,49 & 15,58 & 14,08 & 12,89 \\
\hline Bratislava hl. st. - Berlin Hbf & 69,60 & 53,47 & 43,87 & 37,33 & 32,72 & 29,30 & 26,61 & 24,47 \\
\hline Bratislava hl. st. - Hamburg Hbf & 92,91 & 71,48 & 58,73 & 50,05 & 43,93 & 39,38 & 35,80 & 32,97 \\
\hline Brno hl. n. - Berlin Hbf & 61,08 & 46,40 & 37,67 & 31,73 & 27,53 & 24,42 & 21,96 & 20,02 \\
\hline Brno hl. n. - Hamburg Hbf & 82,25 & 62,28 & 50,39 & 42,31 & 36,61 & 32,37 & 29,03 & 26,39 \\
\hline Praha Holešovice - Berlin Hbf & 36,32 & 27,83 & 22,73 & 19,28 & 16,85 & 15,03 & 13,62 & 12,48 \\
\hline Praha Holešovice - Hamburg Hbf & 53,80 & 41,35 & 33,87 & 28,81 & 25,26 & 22,60 & 20,52 & 18,86 \\
\hline
\end{tabular}

Risk is defined as the opportunity for something that has an impact on the objectives. It is measured by consequences or an estimate of the probability. It is necessary for the railway undertaking to calculate the costs of transport at different occupancy of the train. The final total costs of one seat in the train is an important basis for the tariff formation with the result of eliminating the previous risk and increasing the RU's revenues (Černá et al., 2016). One of the risk elimination options in our case is the determination of the price as the average amount at different train occupancy. The railway undertaking providing this type of services may also face these additional risks:

- financial risk of interest rate increase (if the rolling stock is purchased on credit);

- the risk of capping the amount of compensation for social discounts in the Czech Republic (children, students and seniors are entitled to a $75 \%$ discount);

- compensation risk within the meaning of Regulation (EC) No 1371/2007 (compensations for train delays).
An important means of competition in the market is the acquisition activity of the railway undertaking. With providing the night train services are associated additional services, especially couchette and sleeping services. For determination of the price for additional services is important to know the technological process of the service and the share of costs incurred for its provision. The costs need to be expressed using analytical formulas per calculation unit, in our case per 1 passenger. The following direct costs are included in the additional service sleeping ticket:

- bed sheet costs;

- breakfast package costs;

- employee live labour costs;

- material and other equipment costs.

$$
C_{S}=\frac{C_{B S}+C_{B P}+C_{E L}+C_{M}}{p * n * c}
$$

The formula determined by us is as follows: where:

$\mathrm{C}_{\mathrm{s}}$ - sleeping service costs, 
$\mathrm{C}_{\mathrm{BS}}$ - bed sheet costs,

$\mathrm{C}_{\mathrm{BP}}$ - breakfast package costs,

$\mathrm{C}_{\mathrm{EL}}$ - employee labour costs,

$\mathrm{C}_{\mathrm{M}}$ - material costs,

$\mathrm{p}$ - period or lifetime,

$\mathrm{n}$ - number of trains per day,

$\mathrm{c}$ - passenger occupancy of one wagon.

The price for transport and additional services is formed as a sum of costs and the reasonable profit. For evaluating the economic efficiency, it is necessary to estimate the expected revenues. In our model, we set the price bottom as an average amount of costs by different train occupancy with the reasonable profit of $10 \%$. In Table 6 , we can see calculated price based on average costs and profit by different train occupancy.

Table 6. Profit by different train occupancy (Source: authors)

\begin{tabular}{|c|c|c|c|c|c|c|}
\hline & $\begin{array}{c}\text { average } \\
\text { costs }\end{array}$ & price & $\begin{array}{c}\text { profit } \\
30 \% \\
\end{array}$ & $\begin{array}{c}\text { profit } \\
50 \% \\
\end{array}$ & $\begin{array}{c}\text { profit } 60 \\
\% \\
\end{array}$ & $\begin{array}{l}\text { profit } \\
100 \% \\
\end{array}$ \\
\hline Budapest - Košice & 19,85 & 21,84 & $-12,71$ & $-0,12$ & 3,18 & 9,46 \\
\hline Miskolc - Košice & 8,78 & 9,66 & $-5,88$ & $-0,09$ & 1,42 & 4,32 \\
\hline Košice - Pardubice hl.n. & 28,73 & 31,60 & $-18,35$ & $-0,12$ & 4,51 & 13,62 \\
\hline oprad-Tatry - Pardubice hl.n. & 24,54 & 27,00 & $-15,83$ & $-0,12$ & 3,87 & 11,72 \\
\hline Źilina - Pardubice hl.n. & 18,70 & 20,57 & $-12,31$ & $-0,13$ & 2,96 & 9,05 \\
\hline Budapest - Bratislava hl. & 23,75 & 26,13 & $-16,67$ & $-0,31$ & 3,85 & 12,03 \\
\hline Budapest - Brno hl. n. & 29,44 & 32,38 & $-20,16$ & $-0,31$ & 4,73 & 14,65 \\
\hline Budapest - Praha Holešovice & 28,17 & 30,99 & $-18,72$ & $-0,20$ & 4,50 & 13,76 \\
\hline Budapest - Berlin Hbf & 46,48 & 51,13 & $-30,16$ & $-0,23$ & 7,37 & 22,32 \\
\hline Budapest - Hamburg Hbf & 59,97 & 65,97 & $-38,63$ & $-0,26$ & 9,48 & 28,66 \\
\hline Bratislava hl. st. - Praha Holešovice & 21,36 & 23,49 & $-14,53$ & $-0,20$ & 3,44 & 10,60 \\
\hline Bratislava hl. st. - Berlin Hbf & 39,67 & 43,64 & $-25,96$ & $-0,23$ & 6,31 & 19,17 \\
\hline Bratislava hl. st. - Hamburg Hbf & 53,16 & 58,47 & $-34,43$ & $-0,26$ & 8,42 & 25,50 \\
\hline Brno hl. n. - Berlin Hbf & 33,85 & 37,24 & $-23,84$ & $-0,43$ & 5,51 & 17,21 \\
\hline Brno hl. n. - Hamburg Hbf & 45,20 & 49,72 & $-32,53$ & $-0,67$ & 7,41 & 23,34 \\
\hline Praha Holešovice - Berlin Hbf & 20,52 & 22,57 & $-13,75$ & $-0,16$ & 3,29 & 10,09 \\
\hline Praha Holešovice - Hamburg Hbf & 30,63 & 33,70 & $-20,10$ & $-0,18$ & 4,88 & 14,84 \\
\hline
\end{tabular}

The lower limit of profitability is $60 \%$ occupancy of the train. The railway undertaking must adjust its acquisition activity in such a way as to maintain at least this occupancy of the train. Setting the price with higher amount of reasonable profit can ensure the profitability at lower occupancy but may also cause but it can also lead to an outflow of passengers to competition.

\section{Conclusion}

The liberalised railway transport market offers more and more options for railway undertakings to provide their services on competitive environment. In these conditions it is necessary to be able to estimate the demand for this service, detailed transport technology and form a methodology for calculating the price for transport. Expanding night connections connecting Europe's major cities is also one of the means of achieving carbon neutrality.

The aim of this article was based on analysis of current night train connections to introduce possibilities for new night trains in middle Europe. We focused on connecting important cities in Slovakia, Hungary, Czech Republic, and Germany, and ensuring competitive night connections on international corridor routes. In the article, we proposed timetables, trainset circulations, calculated expected costs and identified possible risks during the provision of this type of services. Based on the costs calculation, we evaluated the economic efficiency of proposed connections and estabilished a methodology for determining the price for additional services, especially couchette and sleeping services.

\section{Acknowledgment}

The paper was supported by the VEGA Agency, Grant No. 1/0379/20 "Socio-economics aspects of rail transport market services deregulation in the context of EU legal framework and sustainable mobility", at Faculty of Operations and Economics of Transport and Communication, University of Žilina, Slovakia.

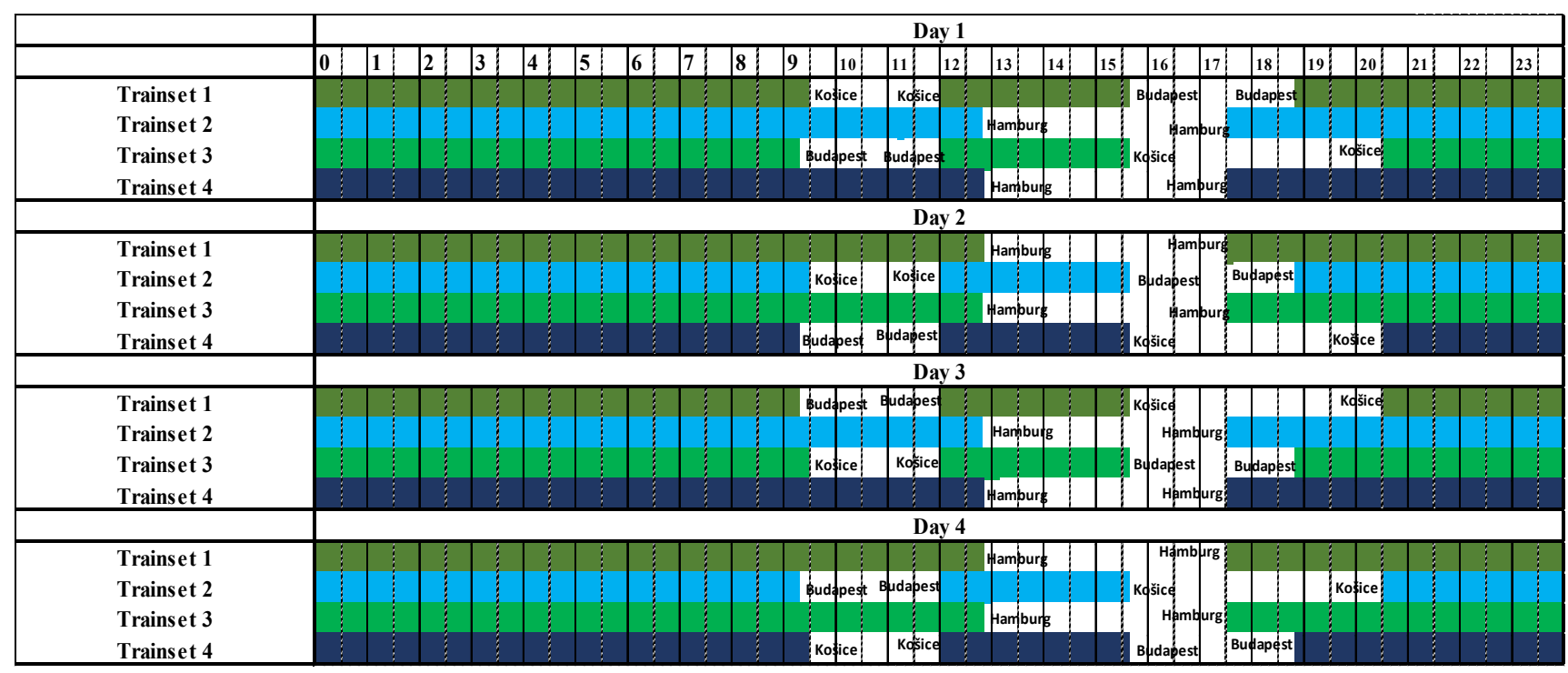

Fig. 2. Trainset circulations (Source: authors) 


\section{References}

cd.cz, 2021. Timetables. Available: https://www.cd.cz/spojeni-ajizdenka/ [Accessed 11 May 2021].

Černá, L., Daniš, J., Dolinayová, A., 2016. Identification of risks in railway transport and the proposal for their price evaluate. In: Transport Means - Proceedings of the International Conference. Vol. 2016. p. 414-419.

Dolinayová, A., Černá, L, Hřebíček, Z., Zitrický, V., 2018. Methodology for the tariff formation in railway freight transport. In: Nase More. Vol. 65. Issue 4 (2018). p. 297304. ISSN 0469-6255.

Dolinayová, A., Nedeliaková, E., 2015. Controlling v železničnej doprave /Controlling in railway transport/. Bratislava: DOLIS. 147 p. ISBN 978-80-970419-9-1.

Gunkel, T., Müller-Hannemann, M., Schnee, M., 2007. Improved search for night train connections. In: OpenAccess Series in Informatics. Vol. 7 (2007). p. 243-258. ISSN 2190-6807.

leoexpress.com, 2021. Timetables. Available: https://www.leoexpress.com/ [Accessed 11 May 2021].

Li, B., Qi, X.-C., Li, Q., Yang, X., 2019. Analysis and prediction of passenger flow of high-speed night train. In: Lecture Notes in Electrical Engineering. Vol. 503 (2019). p. 565576. ISSN 1876-1100.

Manthei, T., 2005. The future of night train services in Europe. In: ZEV Rail Glasers Annalen. Vol. 129. issue 4 (2005). p. 116-123. ISSN 1618-8330.

nightjet.com, 2021. Destinations.

Available:https://www.nightjet.com/en/reiseziele [Accessed 10 May 2021].

Railguideeurope.com, 2021. Night trains in Europe. Available: https://railguideeurope.com/night-trains/ [Accessed 10 May 2021].

Regiojet.cz, 2021. Timetables. Available: https://www.regiojet.cz/ [Accessed 11 May 2021].

Zssk.sk, 2021. Timetables. Available: https://www.zssk.sk/ [Accessed 11 May 2021]. 